\title{
MLL/ARHGEF12 Fusion Gene
}

National Cancer Institute

\section{Source}

National Cancer Institute. MLL/ARHGEF12 Fusion Gene. NCI Thesaurus. Code C99345.

A fusion gene that results from a chromosomal rearrangement which fuses the exon 6

of the MLL gene to most of the ARHGEF12 gene. This rearrangement may be associated with acute myeloid leukemia. 